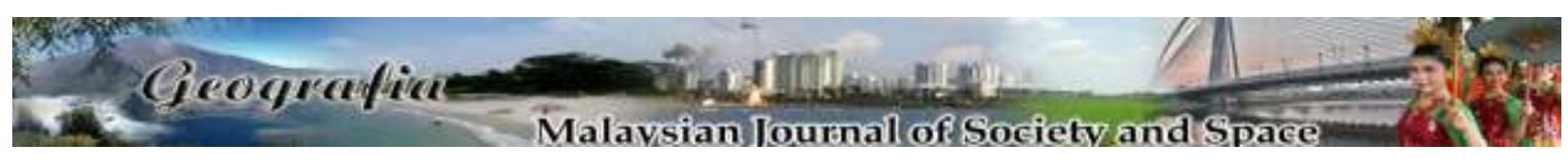

\title{
Health and security nexus in Southeast Asia: Collective securitisation
}

\author{
Nadirah Mohd Azmi \\ Department of Social Studies and Citizenship, Universiti Pendidikan Sultan Idris \\ Correspondence: Nadirah Mohd Azmi (email: nadirah.azmi@fsk.upsi.edu.my)
}

Received: 16 July 2019; Accepted: 20 July 2020; Published: 28 August 2020

\begin{abstract}
This article examines how the Association of Southeast Asian Nations (ASEAN) collectively securitised a non-traditional security issue. Securitisation theory provides a way for government policymakers to devote more attention and resources to issues that might otherwise be overlooked. Securitisation theory, however, is not without significant shortcoming. The framework only emphasises nation-state as the referent object and unit of analysis. By contrast, the characteristics of non-traditional security issue threats require a multilevel relationship, as national solutions are often inadequate. This study, therefore, highlights the process of securitising infectious diseases at the ASEAN level and identifying the types of health challenges that have been collectively securitised. This was done through triangulation of academic materials, ASEAN's official statements and semi-structured elite interviews of the discourse on Southeast Asian health policy between 1967 and 2010. This study argues that only diseases with the potential of becoming a pandemic and threaten the stability of a region have been successfully securitised at the regional level. Additionally, collective securitisation has increase multilateral cooperation among the ASEAN member states.
\end{abstract}

Keywords: ASEAN, collective securitisation, health security, infectious disease, regional.

\section{Introduction}

Securitisation theory (ST) can be described as a process in which some particular threats are classified as security issues by the securitising actor, assigns a special status to the threat, which by doing so, allows the actor the means to legitimise their actions (Buzan \& Wæver, 2003, p. 491). ST offers a clearer view of 'normal' politics heading into the realm of 'unusual' emergency politics. Most importantly, ST addresses the question of how to identify an issue as a security threat without losing its analytical value. These theoretical strengths have made ST become one of the most popular and influential theories developed within security studies (Vuori, 2010).

Despite its advantages, ST is not without conceptual and methodological shortcomings. For instance, how the actors in ST commenced securitisation received scant attention from the 
researchers (Sperling \& Webber, 2016). Moreover, despite the existence of various nations in the world, the framework of ST has only prioritised the nation-state as the reference object (Buzan, Wæver, \& Wilde, 1998). Meanwhile, scholars studying ST have empirically focused on particular states as the unit of analysis (Karyotis, 2012; Robert Glasser, 2016). In contrast, nontraditional security issue (NTS) threats are characterised by their transnational nature, occurring at short notice, and are transmitted rapidly due to globalisation and the communications revolutions (Caballero-Anthony, 2008). Hence, national solutions are often inadequate. Some state and non-state players tend to move to regional and multilevel connections in the quest of responding to the NTS (Caballero-Anthony, Cook, Chng, \& Balen, 2013). Multilateral action has been identified as the most effective way to deal with a new source of threats, mainly through the authority of regional institutions (Pennisi di Floristella, 2012; Zimmerman, 2014).

Since the establishment of ASEAN in 1967, AMS (comprised of 10 states - Brunei, Cambodia, Laos, Indonesia, Malaysia, Myanmar, Philippines, Singapore, Thailand, Vietnam), have always comprehensively dealt with security issues, recognising that the concept of security encompasses a wide range of issues including social, cultural, economic, political, and military. In other words, ASEAN's concept of comprehensive security shows that the institution has recognised the rise of NTS issues for so long (Sukma, 2010). However, cooperation between AMS in addressing the NTS threats is limited as comprehensive security is still very much statecentric. The institution has been paralysed and in disarray for years (Jetschke \& Rüland, 2009) when the management of the NTS issues was left discreetly in the hands of individual member states to be resolved (Caballero-Anthony, 2016). The general perception was that each state faced a distinct threat. Hence, AMS tended to see NTS issues primarily as domestic problems of member states that required a national solution.

Nonetheless, the securitisation framework has been said as "the most widely applied theoretical framework in Southeast Asia" concerning the NTS issues (Jones, 2011, p. 407). This raises an interesting question on whether ASEAN has collectively securitised any NTS issue occurred in the region because the framework does not adequately address how its concept of securitisation can be applied at the regional level (Haacke \& Williams, 2008). This article addresses the gap by applying the securitisation idea to analyse the collective securitisation of health threats in ASEAN. The threat to health has been chosen among other NTS since the intersection between health and security has become more apparent. The region is becoming the hotspot for emerging infectious diseases (Coker, Hunter, Rudge, Liverani, \& Hanvoravongchai, 2011) and the health threat most suitable for securitisation is the outbreak of infectious diseases (Enemark, 2007). Hence, this study also aims to identify the types of infectious disease that have been collectively securitised at the ASEAN level. This article seeks to fill in the gap based on the triangulation of academic material, official statements and documents drawn from ASEAN's leaders and speeches, declarations and communiqués and semi-structured elite interviews (from policy experts to high-ranking public officials) on Southeast Asian health policy discourse between 1967 and 2010.

The article is comprised of several sections. First, it focuses on the steps set out in the roadmap to mutual securitisation. Next, the empirical section starts with an overview of Southeast Asia's policy discourse on health between 1967 and 1990s. It briefly discusses the usual response of AMS to health issues since the establishment of the institution before moving on to the rhetorical securitising of HIV/AIDS spread that occurred between the 1990s and 2000s. It then provides evidence of successful securitisation, demonstrates how the sequence of infectious outbreaks (SARS, H5N1, and H1N1) have occurred in the region over the last decade 
and has contributed to the improvements in regional health policy initiatives, and how they have been implemented. The conclusions drawn from the key findings of the article are; i) AMS only collectively securitised disease at risk of becoming a pandemic, ii) the securitisation framework will improve multilateral cooperation given the fact that each member state faces different levels of threat.

\section{The Collective Securitisation Approach}

The idea of securitization theory draws heavily on the theory of language, specifically from the branch known as 'speech act theory'. Through the theory of language, we can regard 'security' as a speech act. Wæver (1995, p. 35) indicated that 'Security is not of interest as a sign that refers to something more real; the utterance itself is the act. By saying it [security], something is done (as in betting, giving a promise, naming a ship)'. In other words, labelling something as a security issue turns it into such, although this does not necessarily mean that a real threat is present (Buzan et al., 1998).

ST requires specific criteria in the process to change an ordinary issue into a security issue. Buzan et al. (1998) referred to it as a two-stage process. In the first stage, securitising actors (e.g., political leaders) must state that a reference object (something threatened, such as the state or the economy) is existentially threatened. This step is known as the securitising move. To ensure the issue is securitised, the audience should accept the move made by the securitising actor. Thus, in the second stage, for an issue to be regarded as a security issue, the audience must accept the interpretation of events by the actor and recognise that extraordinary measures must be implemented.

Buzan, Waever, and de Wilde emphasised that securitisation requires all the criteria (securitising actors, reference object, existential threat, and emergency measures) to be successful. Such requirements also indicate that not all issues undergoing the securitisation process should automatically be securitised because securitisation is "essentially inter-subjective process" (Buzan et al., 1998, p. 30). Although the securitising actor managed to pose such an existential threat without the approval of the appropriate audience, the threat could not be securitised. Only with the consent of the audience can such a move be followed by putting a 'normal' political issue on the emergency politic agenda. This highlights the importance of intersubjectivity in determining the success of such a process.

In comparison to the normal securitisation process, this article argues that the process does not automatically involve emergency characteristics when deciding what counts as an effective securitisation process (Floyd, 2015). This has the advantage of allowing the ST to be used as a possible explanation of particular outcomes even if they are not 'extraordinary' or 'emergency'. Nevertheless, indicators were set out to identify the extent of ASEAN-level action, namely, policy change or institutional arrangements. These two indicators involve a) the creation of standard policies, and b) the replacement of existing structures or systems with policies that specifically address the issue or the establishment of new institutions, like a task force, alongside existing structures. 
GEOGRAFIA Online ${ }^{\mathrm{TM}}$ Malaysian Journal of Society and Space 16 issue 3 (70-82)

(C) 2020, e-ISSN 2682-7727 https://doi.org/10.17576/geo-2020-1603-06

\section{7-1990 - Health Issues in the Early Days}

This section addresses ASEAN's usual response to health issues since the establishment of the institution until the spread of HIV/AIDS in the late 1990s. Even though health issues in ASEAN have been implicit since the establishment of the institution in 1967, it was only 20 years later that health issues were adequately discussed at the regional level. The ASEAN Health Ministers (AHM) Meeting held in 1980 marked the region's first step towards organising collaboration between AMS on health issues. In their joint communiqué, the leaders agreed to discuss new initiatives and policies collectively aimed at improving the health status of citizens in the region (ASEAN Health Ministers, 1980). Although a regional health institution known as the ASEAN Institute for Health Development (AIHD) was established in 1982, ASEAN's collective stance on health issues was vague as the meeting was not followed by any mechanisms (ASEAN Health Ministers, 1980). Concerning issues like communicable diseases were only categorised as future possible areas of regional collaboration (ASEAN, 1980). The situation continued when AHM met again in 1984, the main agenda being the review of the policies and strategies agreed at the Second Meeting of AHM (ASEAN Health Ministers, 1984). Attention towards health issues remained low between 1984 and 1990, as no AHM meeting was organised during that period, even though ASEAN regional meetings in other sectors were held as usual. The inconsistencies of ASEAN in organising AHM meetings indicated that health issues were not a priority in the regional agenda during the 1980s and early 1990s. Hence, no securitisation elements can be identified in this period.

\section{The 1990s-2000s - The Emergence of HIV/AIDS}

The early 1990s saw a significant policy shift on health issues, when Southeast Asian leaders as securitising actors, first raised concerns about the growing threat posed by HIV/AIDS at the $4^{\text {th }}$ AHM Meeting (ASEAN Health Ministers, 1991). ASEAN leaders had a clear sense of urgency and saw the need for practical cooperation, as stated in the ASEAN Summit 1992 report, whereby the organisation "shall make a coordinated effort in curbing the spread of AIDS by exchanging information on AIDS, particularly in the formulation and implementation of policies and programmes against the deadly disease" (ASEAN Summit, 1992). This indicated that a securitising move had been taken. Practical cooperative measures were also initiated, indicating political commitment among AMS. This included the creation of an ASEAN institutional structure known as the ASEAN Task Force on AIDS (ATFOA), which initiated the first ASEAN Work Programme on AIDS (AWP I) between 1995 and 2000. AWP I focused on prioritising regional cooperation, as well as a range of programmes and activities aimed at improving coordination between AMS in the fight against HIV/AIDS (ASEAN, 2001).

However, in the years that followed, there was a significant change in ASEAN's language. Instead of addressing HIV/AIDS as a regional security issue, ASEAN referred to it as a human security issue - a concept that is primarily concerned with the security of individuals and communities, in marked contrast to the conventional ASEAN security discourse that emphasizes state and regional security. As a result, regional leaders advocated low levels of urgency despite acknowledging the increasing number of people living with the disease in the region. It became evident in the October 2001 British Broadcasting Corporation (BBC) report that Asia was on the verge of an HIV/AIDS crisis. The study found that one in five sex workers 
in Vietnam was HIV-positive, and a ten-fold increase in infection rates was observed in Indonesian blood donors. The infection rates for Cambodia and Vietnam were above the United Nations (UN) epidemic level of 2\% while in Burma (Myanmar), UN officials speculated that the infection rates were more than 7\% (Jagan, 2001). The BBC report showed the lack of urgency among member states, given the fact that initiatives have been enforced for about ten years.

The HIV/AIDS securitising move was largely rhetorical due to the lack of acceptance by the public in terms of member states' commitment to implementing the regional measures that have been initiated. For instance, all AWP I programmes were mostly organised at the state level rather than at the regional level (ASEAN Secretariat, 2002). Moreover, each AMS' views on health issues varied as they have different domestic issues. For instance, the impact of economic crisis and significant political changes in Indonesia in the 1990s had prevented the government from acting swiftly due to the frozen national budget on the health system (Mboi \& Smith, 2006). Meanwhile, in Vietnam, the policy associated with HIV/AIDS is associated with the fight against social evil, as this virus was stigmatised with commercialised sex and drug addiction, resulting in a slow response from the government (Vietnam News Agency, 2002). The delayed impact of HIV/AIDS and domestic constraints mitigate the sense of urgency that often drives decision-making and resource allocation among security planners. The lack of convincing collective mechanisms and the concept of self-reliance in regional collaboration indicated that health issues are generally managed at the national level. As noted by one of the high-ranking officers, "ASEAN [cooperation] perhaps is not strong on HIV" (Officer 6, 2016).

A significant shift in the health issue of securitising movements was identified between 2003 and 2010 when Southeast Asia faced SARS, H5N1, and H1N1 outbreaks. Significant progress has been made in the region during this time in terms of policy and institutional arrangements. Thus, the next segment discusses the health policy debate of Southeast Asia between 2003 and 2010 on the process of securitising infectious diseases collectively.

\section{3-2010 - Series of Infectious Disease Outbreak}

\section{SARS}

In the early stages of SARS, AMS took a unilateral action to address the outbreak. However, a change in the strategy was identified when ASEAN leaders decided to convene regional emergency meetings in Kuala Lumpur and Bangkok, despite the short notice. In the Special ASEAN+3 Health Ministers Meeting held in Kuala Lumpur in April 2003, AMS and their counterparts (China, Japan, and South Korea) jointly articulated a clear sense of urgency about the effects that SARS may pose to the region, as the threat of SARS is not only towards the good health and livelihood of the public but also to the regional economic growth (ASEAN+3, 2003a). Three days later, at the Special ASEAN Summit on SARS and Special ASEAN-China Leaders Meeting, the leaders once again reiterated the statement made at the previous meeting. In their joint declaration, the ASEAN+3 states declared that SARS poses a serious challenge to the wellbeing of the people in the region and the economic development (ASEAN, 2003a).

Both meetings highlight the securitising move and have been significant since there was unprecedented regional efforts had been made to halt the spread of the virus. Meetings of the ASEAN leaders were convened as quickly as possible during the crisis. Compared to ASEAN's response to other issues, it took less than a month following the SARS eruption to convene two regional emergency meetings. The meetings also received tremendous support from AMS when 
it was attended by the heads of government, except for Malaysia, represented by acting Prime Minister Abdullah Badawi. External states leaders from China and Hong Kong also attended the meetings. Besides the AHM meetings, it is important to note that the SARS outbreak was also on the agenda of other ministerial meetings, such as those of the transport and labour ministers, who offered different assessments of the hazards associated with the SARS outbreak (ASEAN+3, 2003b).

Based on the joint declaration and joint statement between ASEAN leaders about the threat posed by SARS in both regional meetings, their statements and speeches showed elements of securitising logic. Positive speech acts can be identified in both joint statements and declarations made at both emergency meetings. Unlike ASEAN's response towards HIV/AIDS, which generated more rhetoric than action, the Bangkok summit final communiqué claimed that there was a "collective responsibility to implement stringent measures to control and contain the spread of SARS and the importance of transparency in implementing these measures" (ASEAN, 2003b). AMS moves in the securitisation of the SARS virus were also followed by substantive practical measures, starting with the shift of strict pre-departure screening at all exit points. Over ten measures were identified in these meetings to curb the spread of SARS, and these measures can be divided into two groups: immediate and short-to-midterm measures. Immediate measures agreed upon including exchanging information on SARS, the best practices in preventive and control measures, contact-tracing for information exchange, and strengthening coordination between front-line enforcement agencies such as health, immigration, customs, transport, and law enforcement to develop travel protocols to ensure that travellers from affected areas are screened for SARS (ASEAN, 2003a). These regional mechanisms were supported by the establishment of a regional fund. A particular ASEAN SARS Fund was set up with China committed to contributing $\$ 1.2$ million, while Thailand offered $\$ 250,000$ and Cambodia $\$ 100,000$ (Macan-Markar, 2003). This special fund was set up to pursue research of SARS in the region.

The presence of ASEAN top leaders showed the urgency and the acceptance of each participant to securitise SARS. The speed with which the regional meetings were called and the establishment of agreed practical cooperation was unprecedented in the history of ASEAN (Curley \& Thomas, 2004). This situation is unique despite each AMS experienced different levels of SARS threat; some states like Singapore were severely affected while states like Cambodia and Laos were reporting fewer cases. The decisions reached the regional meetings would not otherwise have been agreed upon in regular times. This change indicated that ASEAN can respond promptly and that the organisation was able to securitise SARS.

\section{H5N1}

A strong sense of denial of the actual threat posed by H5N1 among AMS government at the early stage of the outbreak was evident. Despite the first confirmed case of H5N1, which occurred within months of the last reported case of SARS at the end of December, a few Southeast Asian countries deliberately withheld vital information on their poultry industries to protect their economies. The Indonesian government, for instance, insisted that no bird flu had been detected in Indonesia although it had been warned that an outbreak of H5N1 had occurred in the state since November 2003. Instead, the Indonesian government blamed the Newcastle disease virus, a contagious and fatal avian virus, for the deaths of thousands of chickens (Taylor, 2004). Similarly, in Thailand, the Thai government declared that the massive amount of chicken 
deaths found in the state in 2003 was due to cholera and bronchitis (Agence France Presse, 2004). However, it soon became evident that the Thai government was aware that the real cause was H5N1 for some time (Cohn, 2004). Meanwhile, Vietnam, which was already aware of the H5N1 outbreak in July 2003, decided to adopt a policy of quiet mitigation because the state was busy preparing for a major sporting event (Deutsche Presse-Agentur, 2004). These three examples were likely to conform to ASEAN's usual practice of unilateral action when faced with a regional threat.

However, the problem of H5N1 among Southeast Asian states has been brought to the brink of regional securitising movement. In late January 2004, Thai's Prime Minister, Thaksin Shinawatra immediately called for a first regional summit, with an affirmative speech act regarding $\mathrm{H} 5 \mathrm{~N} 1$. In the joint statement, AMS leaders stated that H5N1 is "not only severely affecting the poultry industry but also has a potential threat to human health" (ASEAN+3, 2004). This meeting can be considered successful despite it being convened within just three working days (Yuan, 2004). High audience acceptance can be observed when all high-ranking officers from ASEAN were present with other states like Japan, China, South Korea, and the US also joining the summit, in addition to officers from international organisations like the WHO, FAO, OIE, and EU. Since this unprecedented meeting, cooperation among the affected countries in Southeast Asia had improved with governments realising the paramount importance of transparency in combating the virus (Enemark, 2007).

The securitising move continued in the following year. At the $10^{\text {th }}$ ASEAN Summit in Laos in November 2004, the Chairman's Statement articulated a clear sense of urgency in recognising bird flu as one of the 'main challenges' threatening the region (ASEAN, 2004). Following the declaration, a regional task force known as the ASEAN Highly Pathogenic Avian Influenza (HPAI) Task Force was set up in December 2004, signalling a transition to the regional health arrangement. The HPAI Task Force then developed a detailed action plan, which covered eight strategic areas for three years from 2006 to 2008. In the spirit of the task-sharing arrangement, the responsibilities in these eight strategic areas were divided among the group's original members, i.e., Indonesia, the Philippines, Malaysia, Singapore, and Thailand, with each country taking on a specific role (The Straits Times, 2004).

Cooperation commitments were substantiated the following year. As the viral infection peaked in 2005, the threat was the dominant issue in most ASEAN's regional meetings. At the Southeast Asian farm ministers' meeting, the group's deputy secretary stressed that the highly pathogenic avian influenza could become a "region-wide pandemic if left uncontrolled" (Agence France Presse, 2005). The threat continued to prevail in other regional meetings. At the $11^{\text {th }}$ ASEAN Summit in Kuala Lumpur on December 2005, ASEAN leaders welcomed various regional mechanisms. This led to the implementation of practical cooperative measures in addressing the virus. These include the establishment of ASEAN Animal Health Trust Fund (AAHTF), ASEAN+3 Emerging Infectious Diseases Programme (EID), and a regional network of antiviral drugs stockpiles (ASEAN Summit, 2005). These regional mechanisms demonstrated that such regional statements were not mere rhetoric but were backed by substantial resource allocations. For instance, ASEAN+3 EID programme has become a reference point for regional coordination by successfully organising training programmes, seminars, workshops, promoting collaboration between the human and animal health sectors, encouraging the exchange of staff between reference laboratories, and conducting cross-country comparative research on the social and cultural dimensions of infectious diseases (Liverani, Hanvoravongchai, \& Coker, 2012). On the other hand, the establishment of the ASEAN Animal Health Trust Fund suggested that 
member states were prepared to commit extra resources (extra-budgetary reallocation) in furtherance of the regional avian influenza programme. This marked the urgency of the organisation in combating avian influenza at the regional level. Given that only some states in the region were afflicted with the disease, it demonstrated the urgency of ASEAN countries to work together in addressing the issue.

H5N1 remained high on the agenda of ASEAN regional meetings. Following the $11^{\text {th }}$ ASEAN Summit, the first East Asia Summit (EAS) was convened. Apart from the Kuala Lumpur Declaration, which was a declaration on the establishment of EAS, the only declaration adopted during the summit was the Declaration of Avian Influenza Prevention, Control, and Response (East Asia Summit, 2005). This was the region's first declaration of dealing with the bird flu epidemic. This separate declaration reflects the sense of great urgency and imminent danger that prevailed during the outbreak, as well as the need to collaborate in tackling the dreaded avian flu. By doing so, it acknowledged and raised awareness of the pandemic potential caused by the $\mathrm{H} 5 \mathrm{~N} 1$ virus.

H5N1 remained one of ASEAN's main security threat for a few years. According to President Arroyo's statement as Chairperson at the $12^{\text {th }}$ ASEAN Summit, the avian flu was still ranked as a major regional security threat and remained securitised (Arroyo, 2007). The urgency to cope with the virus continued with collaborations between ASEAN and its counterparts; namely China, Japan, and South Korea, as well as international organisations. Starting from 2006 onwards, the ASEAN+3 Health Ministers Meeting was launched. Various regional mechanisms between ASEAN and its counterparts can be traced since then. A Regional Monitoring Centre on Infectious Diseases has been set up with Japan making a new pledge of US\$67 million to fight avian flu and other pandemic diseases (Maier-Knapp, 2011). Meanwhile, a simulation exercise called PanStop was conducted in Cambodia to test the readiness of countries in the region to contain the spread of infection during a pandemic outbreak. This exercise was coordinated by the ASEAN Secretariat with the help of the WHO and the Japanese government.

Despite the lack of government transparency in the early outbreak of H5N1, ASEAN successfully securitised the issue. Having acknowledged the H5N1 threat, political leaders likewise translated their positive speech acts into practical action, including establishing ASEAN HPAI Task Force, increasing disease surveillance, and stockpiling antiviral medicine. The abovementioned speech act was also reinforced by other positive outcomes, such as the establishment of regional financial support ASEAN Animal Health Trust Fund (AAHTF). All AMS agreed to contribute to the fund regardless of $\mathrm{H} 5 \mathrm{~N} 1$ threat on their country. Taking into account the various regional mechanisms that were established and accepted by the AMS, it is possible to maintain that the collective securitisation of $\mathrm{H} 5 \mathrm{~N} 1$ has taken place at the regional level.

\section{H1N1}

Previous outbreaks showed ASEAN acting unilaterally during the early stages of an outbreak. Unlike previous responses, ASEAN was more responsive in dealing with the H1N1 outbreak. In their first response, ASEAN's Secretary-General, Surin Pitsuwan said that "ASEAN member states are better prepared now following the experience of SARS and avian influenza outbreaks" (Pitsuwan, 2009). The organisation started stockpiling antiviral drugs courtesy of Japan and distributed it among member states for rapid response (Channel NewsAsia, 2009). The ASEAN Secretariat has also been fully alerted, 24 hours a day, and seven days a week to anticipate any 
request by member states for antiviral drugs (Malaysia General News, 2009). Also, pertinent information was shared instantly through teleconferences. Notably, this information sharing mechanism between AMS has demonstrated, over a short period, the initial actions of regional emergency measures in response to the threat (Malaysia General News, 2009). The mechanisms used to deal with the outbreak have been significant, as none of the AMS reported any incidents since the confirmation made by the WHO in April 2009. Positive speech acts by various actors could be identified during the emergency meeting. Surin Pitsuwan referred to the virus as a regional concern (Pitsuwan, 2009), while the Thai Prime Minister articulated a clear sense of urgency and shared perceptions about the need for practical regional cooperation (Deutsche Presse-Agentur, 2009). Collective positive speech acts between ASEAN member states could also be identified in their joint declaration during the special meeting (ASEAN+3, 2009).

The securitising speech acts by a wide range of actors and the frequency with which they had been deployed since the official announcement of the H1N1 outbreak have had a demonstrable impact. The speech act used was supported by a wide range of collective regional measures adopted by the member states in the meetings. The measures agreed in the joint ministerial statement include the continuous implementation of the national pandemic preparedness plan, strengthening surveillance and responses, as well as effective communication. Surin Pitsuwan described these collective regional measures as "a booster shot in our common efforts to address this new form of influenza" (ASEAN, 2009a). These regional mechanisms led to the implementation of practical measures to help with protecting state borders, exchanging crucial information, and the mobilisation of antiviral drugs. ASEAN also unanimously enforced strict screening measures. In addition to organising emergency exercises, hotlines between national health authorities have been set up to cut bureaucracy to ensure effective and timely deployment of stockpiles of medicines, medical supplies, and other personal protective equipment (ASEAN, 2009a). The urgency to treat H1N1 as a regional threat continued to be accepted and discussed in other regional meetings. The outbreak caught the eyes of leaders who attended the $4^{\text {th }}$ ASEAN Summit, even though most of the summit agenda focused on Southeast Asia's economic issues and the financial crisis (ASEAN, 2009b).

Compared to previous outbreaks, AMS was proactively responding to the announcement made by the WHO on $\mathrm{H} 1 \mathrm{~N} 1$, although they were not affected in the beginning. This proved that ASEAN, as an organisation, has changed its ways in addressing regional pandemics. The joint statements of member states followed by practical measures also demonstrated that collective securitisation had occurred at the regional level.

\section{Conclusion}

This article set out to analyse whether ASEAN has successfully securitised the health threats collectively. In the early years since the establishment of ASEAN until the end of 1980s, health issues have been viewed as low-level policy issues and received low attention at the regional level, as it was recognised by the institution as a domestic issue. The study revealed that AMS only collectively securitised diseases with the risk of becoming pandemic. Despite attempts to securitise the disease of HIV/AIDS in the early 1990s, ASEAN failed to fully securitise the issue, as it lacked political commitments from the member states. As one of the policy experts said in the interview, "We do prepare for a pandemic. Other health issues from the communicable diseases like $\mathrm{HIV}, \mathrm{Tb}$ [tuberculosis], we address it as [a] public 
issue" (Officer 1 2016). This article demonstrated that collective securitising moves towards health issues had been developed since 2003. Series of infectious disease outbreaks; namely SARS, H5N1, and H1N1 have led ASEAN leaders to develop health problem policy that strengthens cooperation between AMS. Despite each disease outbreak, various regional health mechanisms have been adopted, with AMS facing a different level of threats. This was a crucial development, as opposed to the argument that securitisation is state-centric. Therefore, it could not be implemented on a multilevel basis. More importantly, it also revealed that securitisation has to move ASEAN's cooperation beyond the state-centric understanding of NTS issues.

\section{References}

Agence France Presse. (2004, January 13). Thailand analysing data on possible bird flu. Agence France Presse, pp. 13-14.

Agence France Presse. (2005). Southeast Asian ministers agree on plan to fight bird flu. Agence France Press, 9-11.

Arroyo, M. (2007). Chairperson's Statement of the 12th ASEAN Summit H.E. the President Gloria Macapagal-Arroyo. "One Caring and Sharing Community." Retrieved from http://asean.org/?static_post=chairperson-s-statement-of-the-12th-asean-summit-he-thepresident-gloria-macapagal-arroyo-one-caring-and-sharing-community

ASEAN Health Ministers. (1980). Declaration the ASEAN Health Ministers on Collaboration on Health Manila, 24 July 1980. Retrieved from https://asean.org/?static_post=declaration-theasean-health-ministers-on-collaboration-on-health-manila

ASEAN Health Ministers. (1984). Joint Communique of the Third ASEAN Health Ministers Meeting Pattaya, 9 March 1984. Retrieved from http://asean.org/?static_post=6th-aseanhealth-ministers-meeting-on-healthy-lifestyle-14-15-march-2002-vientiane-chairman-spress-statement

ASEAN Health Ministers. (1991). Joint Press Statement The Fourth ASEAN Health Ministers Meeting Indonesia, 4-5 December 1991. Retrieved from http://asean.org/?static_post=jointpress-statement-the-fourth-asean-health-ministers-meeting-indonesia-4-5-december-1991

ASEAN Secretariat. (2002). The ASEAN Work Programme on HIV/AIDS II (2002-2005). Jakarta.

ASEAN Summit. (1992). Singapore Declaration Of 1992 Singapore, 28 January 1992. Retrieved from https://asean.org/?static_post=singapore-declaration-of-1992-singapore-28-january1992

ASEAN Summit. (2005). Chairman's Statement of the 11th ASEAN Summit "One Vision, One Identity, One Community", Kuala Lumpur. Retrieved from http://asean.org/chairman-sstatement-of-the-11th-asean-summit-one-vision-one-identity-one-community-kuala-lumpur/

ASEAN. (1980). Joint Communique of the Second ASEAN Health Ministers Meeting Manila. Retrieved from http://asean.org/?static_post=joint-communique-of-the-second-asean-healthministers-meeting-manila-22-24-july-1980

ASEAN. (2001). ASEAN' s Efforts in Combating HIV / AIDS. Retrieved from www.asean.org/uploads/archive/ASEAN_combat_aids.pdf

ASEAN. (2003a). Joint Declaration Special ASEAN Leaders Meeting On Severe Acute Respiratory Syndrome (SARS). Retrieved from http://asean.org/?static_post=joint- 
declaration-special-asean-leaders-meeting-on-severe-acute-respiratory-syndrome-sarsbangkok-thailand-29-april-2003

ASEAN. (2003b). Joint Statement of The Special ASEAN + 3 Health Ministers Meeting on Severe Acute Respiratory Syndrome (SARS) "ASEAN is a SARS Free Region". Retrieved from ASEAN Secretariat website: http://asean.org/?static_post=joint-statement-of-thespecial-asean-3-health-ministers-meeting-on-severe-acute-respiratory-syndrome-sars-aseanis-a-sars-free-region-siem-reap-cambodia-10-11-june-2003

ASEAN. (2004). Chairman's Statement of the 10th ASEAN Summit Vientiane. Retrieved from http://asean.org/?static_post=chairman-s-statement-of-the-10th-asean-summit-vientiane-29november-2004

ASEAN. (2009a). 'Full marks' for ASEAN in common defence against Influenza A (H1N1). Retrieved from http://asean.org/?static_post=press-release-full-marks-for-asean-incommon-defense-against-influenza-a-h1n1-bangkok-8-may-2009

ASEAN. (2009b). Chairman's Statement of the 4th East Asia Summit Cha-am Hua Hin, Thailand, 25 October 2009. Retrieved from http://asean.org/?static_post=chairman-sstatement-of-the-4th-east-asia-summit-cha-am-hua-hin-thailand-25-october-2009-2

ASEAN+3. (2003a). Joint Statement ASEAN+3 Ministers of Health Special Meeting on SARS Kuala Lumpur, Malaysia. Retrieved from http://asean.org/joint-statement-asean-3ministers-of-health-special-meeting-on-sars-kuala-lumpur-malaysia/

ASEAN+3. (2003b). Joint Statement of the ASEAN+3 Labour Ministers Meeting Mataram, Indonesia. Retrieved from http://asean.org/?static_post=joint-statement-of-the-asean3labour-ministers-meeting-mataram-indonesia-9-may-2003-2\&category_id=32

ASEAN+3. (2004). Joint ministerial statement on the current poultry disease situation. Retrieved from https://asean.org/joint-ministerial-statement-on-the-current-poultry-disease-situationbangkok-thailand/

ASEAN+3. (2009). Joint Ministerial Statement of the ASEAN+3 Health Ministers Special meeting on Influenza $\mathrm{A}(\mathrm{H} 1 \mathrm{~N} 1)$. Retrieved from ASEAN Secretariat website: http://asean.org/?static_post=joint-ministerial-statement-of-the-asean3-health-ministersspecial-meeting-on-influenza-ah1n1-bangkok-8-may-2009

Buzan, B., \& Wæver, O. (2003). Regions and power: the structure of international security. Cambridge: Cambridge University Press.

Buzan, B., Wæver, O., \& Wilde, J. de. (1998). Security: a new framework for analysis. Colorado: Lynne Rienner Publishers.

Caballero-Anthony, M. (2008). Non-traditional security and infectious diseases in ASEAN: going beyond the rhetoric of securitization to deeper institutionalization. The Pacific Review, 21(4), 507-525.

Caballero-Anthony, M. (2016). An introduction to Non-Traditional Security: a transnational approach. London: SAGE Publications.

Caballero-Anthony, M., Cook, A. D. B., Chng, B., \& Balen, J. (2013). Health. In M. CaballeroAnthony \& A. D. B. Cook (Eds.), Non-traditional security in Asia: issues, challenges and framework for action (pp. 15-40). Singapore: Institute of Southeast Asian Studies.

Channel NewsAsia. (2009, April 27). ASEAN has stockpile of antiviral drugs to deal with swine flu. Channel NewsAsia, pp. 1-2.

Cohn, M. R. (2004, January 24). Patient quarantine urged as bird flu soars. The Toronto Star, p. A16.

Coker, R. J., Hunter, B. M., Rudge, J. W., Liverani, M., \& Hanvoravongchai, P. (2011). 
Emerging infectious diseases in Southeast Asia: regional challenges to control. Lancet, 377(9765), 599-609.

Curley, M., \& Thomas, N. (2004). Human security and public health in Southeast Asia: the SARS outbreak. Australian Journal of International Affairs, 58(1), 17-32.

Deutsche Presse-Agentur. (2004, April 26). 2nd Roundup: Indonesia spares bird-flu-infected fowlEds: Releads on government's decision to spare chickens. Deutsche Presse-Agentur.

Deutsche Presse-Agentur. (2009, May 8). Roundup: Asian health ministers to coordinate fight against A H1N1. Deutsche Presse-Agentur, pp. 1-4.

East Asia Summit. (2005). East Asia Summit Declaration on Avian Influenza Prevention, Control, and Response. Retrieved from http://asean.org/?static_post=east-asia-summitdeclaration-on-avian-influenza-prevention-control-and-response-kuala-lumpur-14december-2005

Enemark, C. (2007). Disease and security: natural plagues and biological weapons in East Asia. Oxon: Routledge.

Floyd, R. (2015). Extraordinary or ordinary emergency measures: What, and who, defines the 'success' of securitization? Cambridge Review of International Affairs, 29(2), 1-25.

Haacke, J., \& Williams, P. D. (2008). Regional arrangements, securitization, and transnational security challenges: the African Union and the Association of Southeast Asian Nations compared. Security Studies, 17(4), 775-809.

Jagan, L. (2001, October 5). Asia warned of AIDS epidemic. BBC. Retrieved from http://news.bbc.co.uk/1/hi/world/asia-pacific/1580333.stm

Jetschke, A., \& Rüland, J. (2009). Decoupling rhetoric and practice : the cultural limits of ASEAN cooperation. The Pacific Review, 22(2), 179-203.

Jones, L. (2011). Beyond securitization: explaining the scope of security policy in Southeast Asia. International Relations of the Asia-Pacific, 11(3), 403-432.

Karyotis, G. (2012). Securitization of migration in Greece: process, motives, and implications. International Political Sociology, 6(4), 390-408.

Liverani, M., Hanvoravongchai, P., \& Coker, R. J. (2012). Communicable diseases and governance: A tale of two regions. Global Public Health, 7(6), 574-587.

Macan-markar, M. (2003, April 29). Health : Asian leaders pledge joint war against SARS. IPSInter Press Service, pp. 1-3.

Maier-Knapp, N. (2011). Regional and interregional integrative dynamics of ASEAN and EU in response to the avian influenza. Asia Europe Journal, 8(4), 541-554.

Malaysia General News. (2009). ASEAN Gears Up to Address Swine Flu. Malaysia General News, pp. 29-30.

Mboi, N., \& Smith, K. H. (2006). Indonesia: Current Status of HIV/AIDS in Indonesia and Prospects for its Spread. In T. Yamamoto \& S. Itoh (Eds.), Fighting a Rising Tide: The Response to AIDS in East Asia (pp. 96-118). Tokyo: Japan Center for International Exchange.

Officer 1. Philippines Health Policy Expert. Manila [March, 2016].

Officer 6. Indonesia High Ranking Public Officials. Jakarta [June, 2016].

Pennisi di Floristella, A. (2012). Are non-traditional security challenges leading regional organizations towards greater convergence? Asia Europe Journal, 11(1), 21-38.

Pitsuwan, S. (2009). The Statement by the Secretary- General of ASEAN on the Outbreak of Swine Influenza ASEAN Secretariat. Retrieved from http://www.asean.org/wpcontent/uploads/archive/PR-SG-Statement-Swine-Influenza.pdf 
Robert Glasser. (2016). The Pandemic Threat to Human Security. The Huffington Post, (February), 2-4. Retrieved from http://www.huffingtonpost.com/A-View-from-the-UnitedNations-/the-pandemic-threat-to-hu_b_9252494.html

Sperling, J., \& Webber, M. (2016). NATO and the Ukraine crisis : Collective securitisation. European Journal of International Security, 2(1), 19-46.

Sukma, R. (2010). ASEAN and non-traditional security. (December), 1-6. Tokyo.

Taylor, R. (2004, January 26). Asia: Indon urges calm after bird flu outbreak confirmed. AAP Newsfeed, pp. 1-3.

The Straits Times. (2004, December 22). ASEAN action plan to fight bird flu. The Straits Times (Singapore), pp. 1-2.

Vietnam News Agency. (2002, March 22). Deputy PM calls for people's active involvement in HIV/AIDS prevention. Vietnam News Agency.

Vuori, J. A. (2010). A Timely Prophet? The Doomsday Clock as a Visualization of Securitization Moves with a Global Referent Object. Security Dialogue, 41(3), 255-277.

Wæver, O. (1995). Securitization and desecuritization. In R. D. Lipschutz (Ed.), On security (pp. 46-86). New York: Columbia University Press.

Yuan, Y. (2004, January 29). Roundup : Regional officials pledge joint efforts to address bird flu crisis by Yuan Yuan. Xinhua General News Service, pp. 77-79.

Zimmerman, E. (2014). Security cooperation in the Indo-Pacific: non-traditional security as a catalyst. Journal of the Indian Ocean Region, 10(2), 150-165. 